\title{
Empirical Research on New Generation of Migrant Worker's Urban Inclusion Based on a Perspective of Psychological, Social and Human Capitals: the data from Jilin Province
}

\author{
Cao Yanling \\ Yatai School of Business Administration, Jilin University of Finance and Economics, Changchun, China
} 328465451@qq.com

Keywords: new generation of migrant worker; psychological capital; social capital; human capital

\begin{abstract}
Based on the central role of human in the process of Chinese New Urbanization, considering their uniqueness and semi-citizenry, this paper did some researches on how to resolve the problem of the new generation of migrant worker's urban inclusion in the context of gradually liberating the household registration system in the process of New Urbanization through empirical research on new generation of migrant worker, using data of Jilin Province, from a perspective of psychological, social and human capitals, in order to solve new generation of migrant worker's urban inclusion problem.
\end{abstract}

\section{Introduction}

There's a phenomenon that the new generation of migrant workers integrate cities deeply in economic aspect but not in social and psychological parts in the process of their urban inclusion. Traditional binary structure resulting from household system is evolving into a new one that new generation of migrant workers are in the status of semi-citizenry, which made their dreams of becoming true citizen and integrate into city encounter lots of embarrasses and resignations.

Although a new household registration policy of comprehensively liberalizing the household registration limit in designated town and small city and opening up the limit in middle-size city in order so as to let migrants enjoy residential treatment increasingly. However, even if the new generation of migrant workers can leap over household registration obstacles caused by urban-rural dual system, they still should live an urban lifestyle, form an urban value, possess psychological capital needed by integration into city, obtain social capital in order to get affectional acceptance by native citizens, and own human capital so that to live and work in urban area in peace and contentment.

Based on the central role of human in the process of Chinese New Urbanization, considering their uniqueness and semi-citizenry, this paper did some researches on how to resolve the problem of the new generation of migrant worker's urban inclusion in the context of gradually liberating the household registration system in the process of New Urbanization through empirical research on new generation of migrant worker, using data of Jilin Province, from a perspective of psychological, social and human capitals, in order to solve new generation of migrant worker's urban inclusion problem.

\section{The Construction of Empirical Research Model on New Generation of Migrant Worker's Urban Inclusion: from a Perspective of Psychological, Social and Human Capitals}

According to the theoretical analysis, we can make the following hypothesis:

H1a: Human capital influences the new generation of migrant workers' social inclusion positively;

H1b: Human capital influences the new generation of migrant workers' psychological inclusion positively;

H2: Human capital influences the new generation of migrant workers' economic inclusion 
positively.

H3a: Social capital influences the new generation of migrant workers' social inclusion positively;

H3b: Social capital influences the new generation of migrant workers' psychological inclusion positively;

H4: Social capital influences the new generation of migrant workers' economic inclusion positively.

H5a: Psychological capital influences the new generation of migrant workers' social inclusion positively;

H5b: Psychological capital influences the new generation of migrant workers' psychological inclusion positively;

H6: Psychological capital influences the new generation of migrant workers' economic inclusion positively.

H7a: Economic inclusion influences the new generation of migrant workers' social inclusion positively;

H7b: Economic inclusion influences the new generation of migrant workers' psychological inclusion positively;

H8aa: Economic inclusion plays an intermediating role between human capital and social capital;

H8ab: Economic inclusion plays an intermediating role between human capital and psychological capital;

H8ba: Economic inclusion plays an intermediating role between social capital and psychological capital;

H8bb: Economic inclusion plays an intermediating role between social capital and psychological inclusion;

H8ca: Economic inclusion plays an intermediating role between psychological capital and social inclusion;

H8ca: Economic inclusion plays an intermediating role between psychological capital and the psychological inclusion.

The empirical research model can be made according to the above hypotheses, as shown in Figure 1. New generation of migrant worker's human capital, social capital and psychological capital influence his economic inclusion, social inclusion and psychological inclusion; new generation of migrant worker's human capital, social capital and psychological capital affect social inclusion and psychological inclusion through economic inclusion. The economic inclusion plays an intermediating role. 


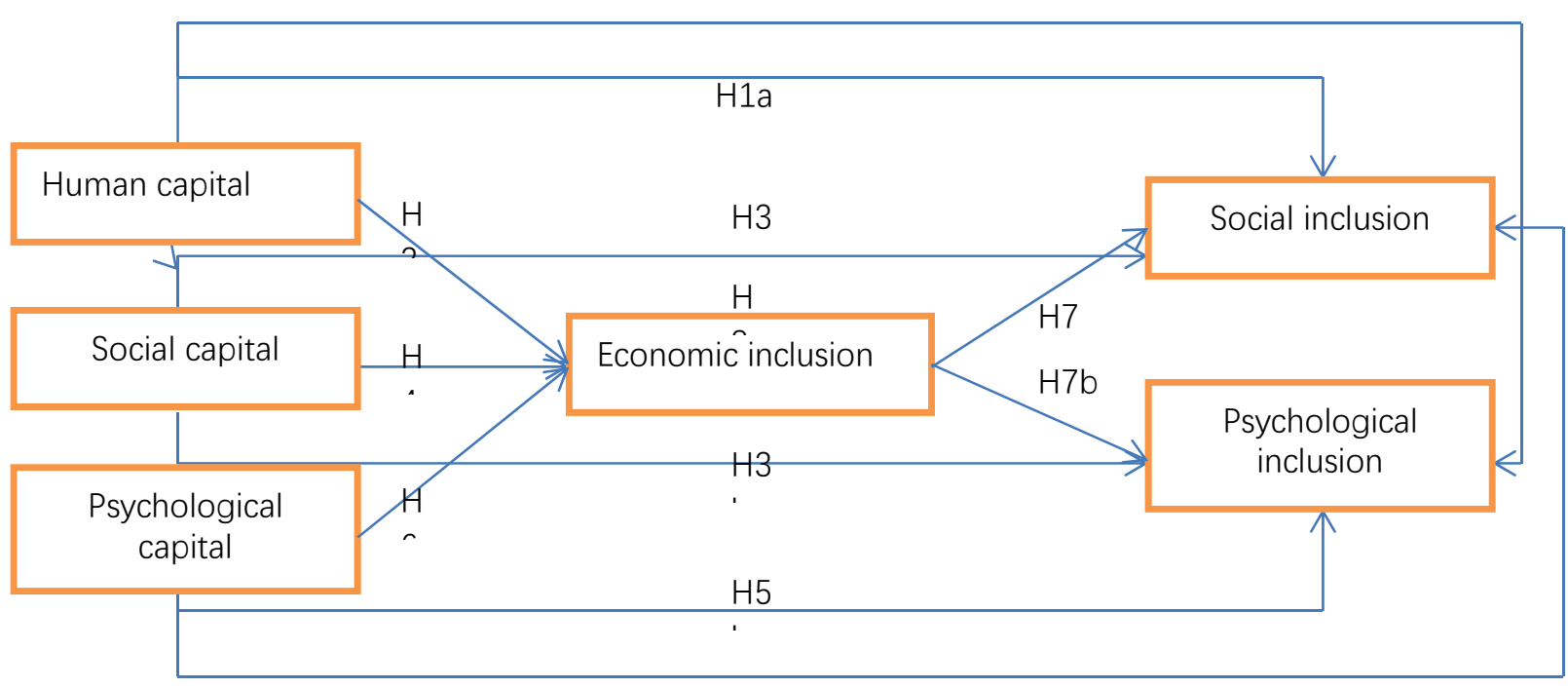

H5

Figure 1 Empirical research model on new generation of migrant worker's urban inclusion: from a perspective of psychological, social and human capitals

\section{Empirical Research on New Generation of Migrant Worker's Urban Inclusion Based on a Perspective of Psychological, Social and Human Capitals: the Data from Jilin Province}

\subsection{The Distribution of Questionnaire}

Taking the urban integration status and influence factors of rural registered permanent residence migrant workers who were born after 1980 and above 16 years old as research object, this paper conducted an investigation in form of questionnaire in the service industry, construction industry, manufacturing, light industry of Changchun City, Jilin City, Yanji City and Baicheng City. This investigation issued 551 questionnaires and there were 419 valid samples.

\subsection{Empirical Analysis Results}

\subsubsection{Human Capital, Social Capital, Psychological Capital and New Generation of Migrant Worker's Social Integration}

Taking human, social, psychological capitals as independent variables, social integration as dependent variable, a liner regression was conducted, the result shown in Table 1. Through the regression analysis, we can find that human capital, social capital and psychological capital influence new generation of migrant worker's social integration in a way. F-test value of the regression equation is remarkable and reaches the level of 0.01 or above, which shows that regression effect is remarkable. Human capital, social capital and psychological capital can explain $88 \%$ social integration. Consequently, the hypothesis $1 \mathrm{a}, 3 \mathrm{a}$ and $5 \mathrm{a}$ are true. 
Table 1 The regression analysis result on human, social, psychological capitals and social integration

\begin{tabular}{|c|c|c|c|c|c|c|}
\hline $\begin{array}{c}\text { Dependent } \\
\text { variable }\end{array}$ & $\begin{array}{c}\text { Independent } \\
\text { variable }\end{array}$ & $\begin{array}{c}\text { Standardized } \\
\text { coefficient }(\beta)\end{array}$ & t-value & Sig. & Adj.R2 & F-value \\
\hline Human capital & \multirow[b]{3}{*}{$\begin{array}{c}\text { Social } \\
\text { integration }\end{array}$} & 0.131 & 4.121 & 0.000 & \multirow{3}{*}{0.888} & \multirow{3}{*}{$\begin{array}{c}1102.84 \\
5\end{array}$} \\
\hline Social capital & & 0.332 & 7.369 & 0.000 & & \\
\hline $\begin{array}{l}\text { Psychological } \\
\text { capital }\end{array}$ & & 0.510 & 11.921 & 0.000 & & \\
\hline
\end{tabular}

\subsubsection{Human Capital, Social Capital, Psychological Capital and New Generation of Migrant Worker's Psychological Integration}

Taking human, social, psychological capitals as independent variables, psychological integration as dependent variable, a liner regression was conducted, the result shown in Table 2. Through the regression analysis, we can draw a conclusion that human capital, social capital and psychological capital influence new generation of migrant worker's psychological integration in a way. F-test value of the regression equation is remarkable and reaches the level of 0.01 or above, which shows that regression effect is remarkable. Human capital, social capital and psychological capital can explain $67.3 \%$ psychological integration. Consequently, the hypothesis $1 \mathrm{~b}, 3 \mathrm{~b}$ and $5 \mathrm{~b}$ are true.

Table 2 The regression analysis result on human, social, psychological capitals and psychological integration

\begin{tabular}{|c|c|c|c|c|c|c|}
\hline $\begin{array}{l}\text { Dependent } \\
\text { variable }\end{array}$ & $\begin{array}{l}\text { Independent } \\
\text { variable }\end{array}$ & $\begin{array}{c}\text { Standardized } \\
\text { coefficient }(\beta)\end{array}$ & t-value & Sig. & Adj.R2 & F-value \\
\hline Human capital & \multirow{3}{*}{$\begin{array}{c}\text { Psychological } \\
\text { integration }\end{array}$} & 0.156 & 2.720 & 0.007 & \multirow{3}{*}{0.673} & \multirow{3}{*}{114.265} \\
\hline Social capital & & 0.403 & 4.569 & 0.000 & & \\
\hline $\begin{array}{l}\text { Psychological } \\
\text { capital }\end{array}$ & & 0.411 & 4.958 & 0.000 & & \\
\hline
\end{tabular}

Regression equation: social integration $=0.156 \times$ human capital $+0.403 \times$ social capital $+0.411 \times$ psychological capital +0.332

\subsubsection{Human Capital, Social Capital, Psychological Capital and New Generation of Migrant Worker's Economic Integration}

Taking human, social, psychological capitals as independent variables, economic integration as dependent variable, a liner regression was conducted, the result shown in Table 3. Through the regression analysis, we can draw a conclusion that human capital, social capital and psychological capital influence new generation of migrant worker's economic integration in a way. F-test value of the regression equation is remarkable and reaches the level of 0.01 or above, which shows that regression effect is remarkable. Human capital, social capital and psychological capital can explain $88.9 \%$ economic integration. Consequently, the hypothesis 2,4 and 6 are true.

Table 3 The regression analysis result on human, social, psychological capitals and economic integration

\begin{tabular}{|c|c|c|c|c|c|c|}
\hline $\begin{array}{l}\text { Dependent } \\
\text { variable }\end{array}$ & $\begin{array}{l}\text { Independent } \\
\text { variable }\end{array}$ & $\begin{array}{c}\text { Standardized } \\
\text { coefficient }(\beta)\end{array}$ & t-value & Sig. & Adj.R2 & F-value \\
\hline Human capital & \multirow{3}{*}{$\begin{array}{l}\text { Economic } \\
\text { integration }\end{array}$} & 0.128 & 5.595 & 0.000 & \multirow{3}{*}{0.889} & \multirow{3}{*}{561.083} \\
\hline Social capital & & 0.334 & 8.576 & 0.000 & & \\
\hline $\begin{array}{l}\text { Psychological } \\
\text { capital }\end{array}$ & & 0.549 & 12.505 & 0.000 & & \\
\hline
\end{tabular}




\subsubsection{Economic Integration and Social Integration, Psychological Integration}

Taking economic integration as independent variable, social integration and psychological integration as dependent variables, we can conduct liner regression respectively, then the result is shown in Table 4. Through the regression analyses, we can find that economic integration influences new generation of migrant worker's social and psychological integration in a way. F-test value of the regression equation is remarkable and reaches the level of 0.05 or above, which shows that regression effect is remarkable. Economic integration can explain $90.4 \%$ social integration and $69.2 \%$ psychological integration. Consequently, the hypothesis $7 \mathrm{a}, 7 \mathrm{~b}$ are true.

Table 4 The regression analysis result on economic integration and social, psychological integration

\begin{tabular}{|c|c|c|c|c|c|c|}
\hline $\begin{array}{c}\text { Dependent } \\
\text { variable }\end{array}$ & $\begin{array}{c}\text { Independent } \\
\text { variable }\end{array}$ & $\begin{array}{c}\text { Standardized } \\
\text { coefficient }(\beta)\end{array}$ & t-value & Sig. & Adj.R2 & F-value \\
\hline \multirow{2}{*}{$\begin{array}{l}\text { Economic } \\
\text { integration }\end{array}$} & $\begin{array}{c}\text { Social } \\
\text { integration }\end{array}$ & 0.879 & 62.627 & 0.000 & 0.904 & 3922.201 \\
\hline & $\begin{array}{l}\text { Psychological } \\
\text { integration }\end{array}$ & 0.850 & 30.674 & 0.000 & 0.692 & 940.865 \\
\hline
\end{tabular}

\subsubsection{The Mediating Effect Analysis on Economic Integration as an Intermediary Variable between Psychological, Social, Human Capital and Social, Psychological Integration}

The result of hierarchical regression is shown in table 5. From the result of analysis, we can find human capital, social capital, psychological capital enters regression equation along with economic integration at the same time when social integration as independent variable, explanatory power of the three-capital to social integration increases $3.0 \%$, to $91.9 \%$. Now the regression coefficients of human capital, social capital and psychological capital are still remarkable $(p<0.01)$, but the original regression coefficients decrease to varying degrees; Explanatory power of the three-capital to psychological integration increases $2.5 \%$, to $69.8 \%$. Now the regression coefficients of human capital, social capital and psychological capital are still remarkable $(p<0.01)$, but the original regression coefficients decrease to varying degrees. That is, after controlling demographic variable, human capital, social capital and psychological capital enter the regression equation, the effect of three dependent variables on social and psychological is weakened, then the above step three of mediation inspection is satisfied. Consequently, economic integration plays a partial mediating role between human capital, social capital, psychological capital and social integration, psychological integration. The hypothesis $8 \mathrm{aa}, 8 \mathrm{ab}, 8 \mathrm{ba}, 8 \mathrm{bb}, 8 \mathrm{ca}, 8 \mathrm{cb}$ are proved to be true.

Table 5 The mediating effect analysis on economic integration as an intermediary variable

\begin{tabular}{|c|c|c|c|c|c|c|c|}
\hline Variable & $\begin{array}{c}\text { Human } \\
\text { integration }\end{array}$ & $\begin{array}{c}\text { Social } \\
\text { integration }\end{array}$ & $\begin{array}{c}\text { Psychological } \\
\text { integration }\end{array}$ & $\begin{array}{c}\text { Economic } \\
\text { integration }\end{array}$ & F-value & Adj. $\mathrm{R}^{2}$ & $\triangle \mathrm{R}^{2}$ \\
\hline $\begin{array}{c}\text { Social } \\
\text { integration }\end{array}$ & 0.037 & 0.148 & 0.266 & 0.528 & 675.481 & 0.919 & 0.030 \\
\hline $\begin{array}{c}\text { Psychological } \\
\text { integration }\end{array}$ & 0.061 & 0.210 & 0.117 & 0.547 & 139.036 & 0.698 & 0.025 \\
\hline
\end{tabular}

\section{Conclusion}

\subsection{The Relationship between the Three Capitals and New Generation of Migrant Worker's Economic Integration}

Human capital, social capital, psychological capital effect new generation of migrant worker's economic integration positively. That is to say, new generation of migrant workers owning more and more human capital tends to hunt more stable and higher paid job, so that they can integrate urban area well economically and be more security economically. New generation of migrant workers who having more social capital intercourse with local residents and have more source to 
get information, then they will have more opportunities to get higher income. New generation of migrant workers possessing higher psychological capital are more hardworking and optimistic, so they are qualified to have stronger psychological motivation and self-efficacy to seek higher economic income.

\subsection{The Relationship between the Three Capitals and New Generation of Migrant Worker's Social Integration}

Human capital, social capital, psychological capital effect new generation of migrant worker's social integration positively. New generation of migrant workers owning higher human capital will be employed a higher-level career. On this basis, wider social intercourse results in they integrate urban community better subjectively. New generation of migrant workers owning higher social capital intercourse with more local residents, participant activities of local communities, therefore, they can identify urban lifestyle and improve their social integration level. New generation of migrant workers owning stronger psychological capital are independent, autonomous and thankful. They possess higher emotional intelligence and adapting ability, subsequently they identify urban area psychologically and have higher social integration level to urban area.

\subsection{The Relationship between the Three Capitals and New Generation of Migrant Worker's Psychological Integration}

Regression result shows that economic integration affect new generation of migrant worker's social integration and psychological integration to some extent. When new generation of migrant worker having higher economic integration, they have higher income and higher security and more expectation about the future, they possess more disposable income to fulfil urban lifestyle and maintain more urban life circle and friend circle, they will become real local residents. Additionally, higher and more stable income will prompt people to conceive a thought of living and working in peace and contentment. Then they will create a sense of belonging psychologically and never be worried about local residents will discriminate against them for their poverty, which will increase their psychological integration degree.

\subsection{Economic Integration Plays a Mediating Role between Psychological, Social, Human Capital and Social, Psychological Integration}

In the regression conclusion, economic integration is taken as a mediating variable between the three capitals and social capital, psychological capital, which enables the three capitals influence social integration and psychological integration partially through influence economic integration. Higher level the three capitals will accelerate new generation of migrant worker's economic integration, while the new generation of migrant worker with higher, stable income and better expectation about future identify urban lifestyle and own the sense of belonging in urban area, which will prompt social and psychological integration partially. Additionally, because economic integration plays a partial mediating role between the three capitals and social integration, psychological integration, that is to say, the three capitals just effect social and psychological integration partially through economic integration, and another part effect is caused by the three capital's direct effect on social and psychological.

\section{Acknowledgements}

This paper is a periodic achievement of a Scientific Research Project of Jilin University of Finance and Economics (No. 2017B29) and 13th Five-Year Plan Scientific Research Project of Education Department of Jilin Province (No. JJKH20180487SK).

\section{References}

[1] Wang Dianli, Liu Baojiu, Lou Suping. (2011) New Generation of Migrant Workers Integrating into Urban Society: Frame Construction and Survey Analysis. Chinese Public Administration. 2, 
111-115.

[2] Zhou Yexin, Ye Jingyi, Cao Heping. (2013) Social Capital Measurement of Migrant Workers and Their Distribution Characteristics: An Analysis Based on the Social Network of Migrant Workers in Beijing. Journal of Yunnan University of Finance and Economics 3, 141-151.

[3] Chen Yanqiu, Jin Xiaotong. (2014) Empirical Study on the Influencing factors of the New Generation Migrant Workers' Citizenization Willness: Based on the Investigation of human capital, social capital and Psychological capital. Northwest Population Journal. 4, 105-111.

[4] Baron R A A G. (2000) Beyond Social Capital: How Social Skills and Enhance Entrepreneurs' Success. Academy of Management Executive. 14, 61.

[5] Kumar C S. (2006) Human Capital and Growth Empirics. The Journal of Developing Areas. 40, 15. 